\title{
Investigating the Application of Needs Analysis on EAP Business Administration Materials
}

\author{
Saifalislam Abdalla Hajahmed Mohammed ${ }^{1,2}$ \\ ${ }^{1}$ Jubail Industrial College, Al-Jubail, Saudi Arabia \\ 2 El-Sheikh Abdalla El-Badri University, Gadawab, Sudan \\ Correspondence: Saifalislam Abdalla Hajahmed Mohammed, Jubail Industrial College, Al-Jubail, Saudi Arabia. \\ Tel: 966-536-976-045. E-mail: abufag@yahoo.com
}

\author{
Received: January 5, 2016 Accepted: February 11, 2016 Online Published: February 13, 2016 \\ doi: 10.5539/elt.v9n3p74 URL: http://dx.doi.org/10.5539/elt.v9n3p74
}

\begin{abstract}
This study is conducted to investigate the application of needs analysis in developing EAP materials for business administration students in two Sudanese universities. The subjects are 2 head departments of English language. To collect data, the researcher uses interview and content analysis. The study adopts the descriptive approach. The data of the study is analyzed qualitatively. The findings show that most of the business administration EAP materials in Sudanese universities are not based on needs analysis and are not relevant to the students' learning and target situation needs. The drawbacks in EAP materials, in Sudanese universities, are due to the absence of needs analysis practice in the process of syllabi design. Therefore, the researcher recommends the application of needs analysis in the process of course design to assure designing courses that are relevant to the students' actual needs. The EAP courses which are taught in Sudanese universities should be tailored to the students' specific needs.
\end{abstract}

Keywords: English for specific purposes, English for academic purposes, Arabicization

\section{Background}

After the implementation of Arabicization in higher education in 1990, English had become one of the subjects among others in the curriculum. This place dictates the necessity of thorough investigations to both the learners' needs and the EAP courses taught in Sudanese universities.

It has been noticed in most of the Sudanese universities, there are not any kinds of readymade EAP materials designed by experts in the field of syllabus design. The EAP teachers compile the EAP materials by themselves. The product is more likely to be inadequate. Such inadequacy in EAP materials has triggered the need to investigate this problem as an urgent ELT issue in tertiary education in Sudan.

The present study comes as a result of the observation that students who study EAP courses in Sudanese business administration schools are weak in English language and cannot understand the terminologies of their specialty in English. This might be attributed to the absence of needs analysis. The present study will examine to what extent is this factor behind this problem.

The main objectives of the study are to examine whether the EAP materials, which are taught to business administration students in Sudanese higher institutions are based on the learners' learning needs analysis and the target situation analysis. Also, to shed light on the necessity of learners' needs and target situation needs in the process of syllabus design.

\section{Literature Review}

\subsection{English for Academic Purposes}

English for academic purposes was defined by so many scholars and authors. For Jordon, 1997 it is the teaching of English language with the aim of facilitating the learners' study or research in that language. English for academic purposes can be divided into two types: English for general academic purposes and English for specific academic purposes. English for general academic purposes includes the notes taking, listening to lectures and using dictionaries and English for specific academic purposes like medical English, business English, scientific English and English for science and technology. 


\subsection{EAP Situation in Sudan and its Historical Background}

English for academic purposes (ESP/EAP) is a compulsory subject for the first four semesters in most of the Sudanese universities. It is one of the university requirements that the students have to study in the first four semesters. However, students are more concerned with how to pass the exam rather than to fulfill any development in the language field. Even the teachers pay little attention to the development of the learners' competence.

Ibrahim, 1980 states that EAP is taught for Sudanese tertiary level students in the first two levels, but the students pay little or no attention to it and they graduate to find it difficult to use English language in the workplace. Most of the EAP learners at Sudanese universities believe that the syllabus is not suitable and needs to be modified to satisfy all their needs. Also the EAP instructors focus on general English and pay little attention to EAP.

The academic year 1965/66 witnessed the application of Arabicization in all the Sudanese schools. English language was the medium of instruction but after 1965 it became a subject among other subjects in the school timetable. Arabic language became the medium of instruction in schools. However, the students were faced by so many problems when they entered the universities. The sudden change from Arabic medium of instruction system to English medium of instruction system caused so many problems to the students when they entered universities. To find a solution for this immediate transition from Arabic to English, ESP was introduced in Sudanese universities to fill the gap between the students' real level and the level needed to continue the study at Sudanese higher institutes. As a result English Language Service Unit (ELSU) was established at University of Khartoum in 1975. The academic year 1990/1991 witnessed the application of Arabicization in tertiary level. Arabic language became the medium of instruction in all the Sudanese universities and higher institutes. In 1996 University of Khartoum introduced the university requirements: English language, Arabic language, computer studies, Islamic studies and Sudanese studies.

\subsection{What Is Needs Analysis}

Needs analysis is the corner stone in the process of designing an English for specific purposes (ESP) course, and many scholars and authors stated its importance.

According to Iwai (1999), the term needs analysis generally refers to the activities that are involved in collecting information that will serve as basis for developing a curriculum that will meet the needs of a particular group of students.

Brindley (1989) offers definitions of different types of needs and accounts of various problems and limitations in making use of this concept, including ways in which one might usefully distinguish between needs identified by analysts and those expressed or experienced by learners. In his state-of-the-art article, West (1994) gives a thorough overview of needs analysis in language teaching, including its history, theoretical basis, approaches to needs analysis, etc.

According to Iwai (1999), formal needs analysis is relatively new to the field of language teaching. However, informal needs analyses have been conducted by teachers in order to assess what language points their students need to master. In fact, the reason why different approaches were born and then replaced by others is that teachers have intended to meet the needs of their students during their learning. For Johns (1991), needs analysis is the first step in course design and it provides validity and relevancy for all subsequent course design activities.

\section{Research Questions}

1) Are EAP materials, which are taught to business administration students in Sudanese universities, based on the learners' learning needs analysis and the target situation needs analysis?

2) Are the drawbacks in EAP materials, in Sudanese universities, due to the absence of needs analysis practice in the process of syllabus design?

\section{Method}

The structured interview was administered to the head of English departments in the two Sudanese universities, Shendi University and Nile Valley University and the head of department were chosen because they are responsible for the EAP courses in the faculties of business administration. The interviewees have to choose from some given choices. The data collected from the structured interview was analyzed qualitatively. There is also a document analysis for the EAP materials in the two universities. Because there are not any kinds of readymade materials, the researcher just used samples of EAP materials from the two universities. 


\section{Discussion and Limitations}

\subsection{Shendi University - Content Analysis of Business Administration EAP Materials}

These EAP materials were compiled to be used by the students of business administration at Shendi University. The EAP courses are supposed to train a good reader, writer, listener and speaker of English related to the field of business administration. However, the main objective of the material is to help business students to develop their general language knowledge not to develop the ability to handle the kind of written English that they will encounter during the pursuit of their academic education. Most parts of materials are based on structural, Lexical Approach. The language points of these EAP materials are not related to vocabulary and special terms and the expressions that business students need. The materials is lacking from some of useful vocabulary for business administration students. Some examples are: headquarters, accounts department, A.G.M (annual general meeting of a company's shareholders), chairman, director, managing director, personnel department, executive director, shareholders, and vice president. The majority of exercises provided by these materials are on grammar and vocabulary, no use of speaking and listening skills could be found. Grammar is taught deductively. The students are given the rules and they are asked to apply the rules.

The materials are not helpful enough for students to guess the meaning of unfamiliar words. The materials covered few specialized business texts. There are no models of business letters. The subject-matter areas of these EAP materials are not attractive, and the level of the material is lower than the assumed English level of students (repetition of English tenses which the students have already studied at higher secondary schools). The topics of texts are not related to business administration field. In fact, effectiveness, appropriateness, and feasibility of the material to students' interests and language level are not satisfying. It mostly focuses on the reading skill, grammar rules and vocabulary of general English. The contents of materials have a logical sequence. The materials start with easy activities and ends with the difficult ones. It is based on the behaviourism theory of learning. The exercises in these EAP materials focus on reading comprehension. Little or no attention has been paid to production and language use. Audio-visual equipments are not used through this course as listening skill is neglected. The materials are photocopied materials so, there are not colourful picture to attract the students' attention. It adopts traditional methods of teaching language like grammar translation method. Vocabulary and terminologies are not introduced in context. The students are given list of words and their equivalents in Arabic.

\subsection{Nile Valley University - Content Analysis of Business Administration EAP Materials}

These EAP materials are taught to the business administration students at Nile Valley University. The courses are supposed to develop the students' professional communication skills with more emphasis on reading and writing, however these materials violate the objectives of the course. These materials try to develop the students' general language knowledge. The language points that covered by these EAP materials do not correlate with the actual needs of the learners and the objectives of the course. It covered the tenses and some of everyday vocabulary. Grammar is given the priority. Most of the texts in the EAP materials are general English texts. The writing and reading skills which are highly needed by the EAP learners are completely neglected. Vocabulary and terminologies are not introduced in context. Vocabulary is introduced in isolation. The students are given lists of vocabulary and terminologies and their equivalents in Arabic.

The EAP materials are based on the behaviourists theory of learning. The affective and cognitive theories of learning are not adopted by the EAP materials. So the materials do not motivate the students to learn English language. The learners are passive recipients and the teacher is source of knowledge. The materials also adopted out of date language teaching methods. The micro-skills like guessing the meaning of unfamiliar word is not covered by the EAP materials. The students either get the meanings from the teachers or from the dictionaries. The EAP materials adopted the grammar translation method as a method of teaching. Most of the exercises are reading comprehension and vocabulary exercises. There are not so many language use and production exercises. The content is sequenced from easy to difficult. The aids like overhead projection, pictures, audio visual equipment, computer, multimedia and internet are not used in the EAP materials.

The language points that covered by the EAP materials do not correlate with the actual needs of the learners. It covered the tenses and some of everyday vocabulary. The topics of texts are not related to business administration field. In fact, effectiveness, appropriateness, and feasibility of the material to students' interests and language level are not satisfying. The level of the material is lower than the assumed English level of students (repetition of English tenses, which the students have already studied at higher secondary schools).

\subsection{Interview}

The following is a summary of feedback obtained from the interviews conducted with the heads of English 
language departments at Shendi University and Nile Valley University. The responses are summarized below:

The interviewees from the two universities state that the EAP courses taught at the two universities are not usually based on the results and findings of needs analysis. According to the interview responses, the EAP teachers from both Shendi University and Nile Valley University never raise arguments about needs analysis. There is no ESP/EAP service unit for teaching EAP courses in all the interviewees' universities. EAP courses are taught by the departments of English language at the two universities. At Shendi University, the EAP courses are run by the departments of English language in the faculty of Arts. At Nile Valley University, the department of English language in the faculty of Education is responsible for all the EAP courses in the university. There are not any readymade textbooks that are designed by professional syllabus designers, taught in the two universities. The EAP teachers at the two universities have the right to compile and select the contents of the EAP course. The interviewee from Shendi University thinks that the EAP materials at Shendi University do not address the students' specific needs. The interviewee from Nile Valley University thinks that the EAP materials at the university to some extents address the students' specific needs. According to interview responses, the interviewee from Shendi University sometimes asks the EAP teachers in the departments to teach readymade material to business administration students. The interviewee from Nile Valley University never asks the EAP teachers to teach readymade materials to business administration students. The interviewee from Shendi University states that the teachers in the university are not keen to develop the EAP courses in the department. The interviewee from Nile Valley University states that some of the EAP teachers are keen to develop the courses they teach. The interviewee from Shendi University believes that the EAP courses which are taught to business administration students are not relevant to the field of the students. The interviewees from Nile Valley University believes that the EAP taught to business administration students are relevant to some extent to the students' field. The interviewee from Shendi University believes that the EAP courses which are taught at Shendi University to business administration students in particular and the other fields in general will meet the students' learning and future career needs. The response of the interviewee from Shendi University contradicts the response to the question number (1). The interviewee from Nile Valley University believes that the EAP courses which are taught to business administration students in particular and other fields in general will meet to some extent the students' learning and future career needs. According to the interview responses, the EAP teachers Nile Valley University are allowed to compile what they think is relevant to the students' specific needs. The EAP teachers at Shendi University are not allowed to compile what they think is relevant to the students' specific needs. The response of the interviewee from Shendi University to this question contradicts the response to question number (1). There are not any readymade EAP materials at the two universities for business administration students.

\section{Conclusion and Recommendations}

The results obtained from the analysis of the EAP materials of the two Sudanese universities have shown that most of the vocabulary and terminologies in these materials are not relevant to the field of business administration and these materials adopted out of date language teaching methods. Most of the exercises and the activities in these EAP materials do not serve the objective of teaching EAP courses to business administration students (development of the students' professional communication skills). This answers the second question and confirms the hypothesis that most of EAP materials, which are taught to business administration students in Sudanese higher institutions do not match the learners' learning and target situation needs.

The results of the structured interview have shown that the EAP teachers at the two universities compile the course materials themselves and there are not any kind of readymade EAP materials. This provides an answer to the first question and confirms the hypothesis that the EAP materials, which are taught to business administration students at Sudanese universities are not based on learners' learning and target situation needs analysis.

In the light of the study findings, the researcher recommends the following:

- Needs analysis should be an indispensable tool in the process of syllabus design.

- The EAP courses, which are taught in Sudanese universities, should be tailored to the students' specific needs.

- The EAP courses, which are taught at Sudanese universities, should regularly be reviewed and modified.

- There should be a technical committee for the regular review and development of the EAP materials in all the Sudanese universities.

- To satisfy the students' real needs, the students' voice should be heard during the process of syllabus design.

- Cooperation need to be enhanced with subject teachers, EAP teachers as well as with students. 


\section{References}

Alexander, O., Argent, S., \& Spencer, J. (2008). EAP Essentials: A teacher's guide to principles and practice. Reading: Garnet.

Brindley, G. P. (1989). The role of needs analysis in adult ESL Programme design. In R. K. Johnson, (Ed.), The Second Language Curriculum. Cambridge: Cambridge University Press. http://dx.doi.org/10.1017/CBO9781139524520.007

Brown, J. D. (1995). The elements of language curriculum: A systematic approach to program development Boston, Massachusetts: Heinle \& Heinle Publishers.

Chambers, F. (1980). A re-evaluation of needs analysis. ESP Journal, 1, 25-33. http://dx.doi.org/10.1016/0272-2380(80)90007-4

Dudley-Evans, T., \& St. John, M.-J. (1998). Developments in ESP: A multi-disciplinary approach. Cambridge, U.K.: New York.

Hutchinson, T., \& Water, A. (1993). English for specific purposes: A learning centered approach. Cambridge: Cambridge University Press.

Hutchinson, T., \& Water, A. (1997). Life Lines Intermediate English Course. Oxford: Oxford University Press.

Ibrahim, A. (2010). ESP at the Tertiary Level: Current Situation, Application and Expectation. English Language Teaching, 3(1). http://dx.doi.org/10.5539/elt.v3n1p200

Iwai, T., Kondo, K., Limm, S. J. D., Ray, E. G., Shimizu, H., \& Brown, J. D. (1999). Japanese language needs analysis. Retrieved from http://www.nflrc.hawaii.edu/Networks/NW13/NW13.pdf.

Johns, A. (1991). English for specific purposes: Its history and contributions. In M. Celce-Murcia (Ed.), Teaching English as a second or foreign language (2nd ed., pp. 67-77). Boston, Massachusetts: Heinle \& Heinle. http://dx.doi.org/10.1016/0889-4906(91)90011-K

Jordan, R. R. (1997). English for academic purposes: A guide and resource book for teachers. Cambridge England; New York: Cambridge University Press. http://dx.doi.org/10.1017/CBO9780511733062

Soriano, F. (1995). Conducting Needs Assessments A Multidisciplinary Approach. Sage Human: Services Guide \#68. Sage Publications: Thousand Oaks, CA.

West, R. (1994). Needs Analysis in Language Teaching.

\section{Appendix.1}

This interview is intended to collect data about the educational environment where EAP operates, for the purpose of identifying the kind of problems and difficulties that face both the EAP teachers and learners and to achieve the objectives of teaching EAP courses for business administration students.

Thank you very much for your cooperation. 


\section{The Questions}

1. Are the EAP courses in your university organized and run by:
a. A service unit
b. A department of English
c. others

Please specify

2. Are the EAP courses you teach in your university for business administration students relevant to their field of study?

$$
\text { Yes } \square \text { ome extent }
$$

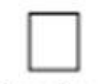

No

3. Are the EAP course materials taught in your university:
a. Ready-made materials
b. Teachers-compiled materials

4. Do you think the EAP materials in your department address the students' specific needs?

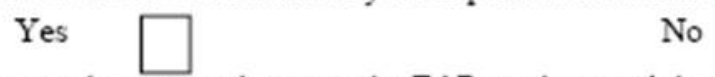

5. Is there a regular contact between the EAP teachers and the business administration teachers with regard to students' EAP needs?
Yes
$\square$
No

6. Do you feel that the EAP courses you teach in your university to business administration students in particular and the other fields in general will meet their learning and future career needs?
Yes
to some extent
No

7. Do you ask the EAP teachers in your department to teach ready-made materials?
Sometimes
rarely
never

8. Are the EAP courses taught at your university usually based on the results and findings of needs analysis?
Yes
No

9. Are the EAP teachers in your department allowed to compile what they think is relevant to their students' specific needs?

Yes $\square$

No

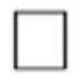

10. Are the EAP teachers in your university keen to develop the courses they teach?
Some of them

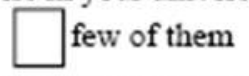
None of them

11. Do EAP teachers in your university raise arguments about needs analysis?

12. Are there readymade EAP materials in your department for business administration students? Yes

\section{Copyrights}

Copyright for this article is retained by the author(s), with first publication rights granted to the journal.

This is an open-access article distributed under the terms and conditions of the Creative Commons Attribution license (http://creativecommons.org/licenses/by/3.0/). 